as in other global contexts, these were effectively barred from receiving ordination. Even as the Jesuits were spreading the faith in all corners of the world, the idea of a globally diverse priesthood, in Sachsenmeier's words, "was often perceived as a potential erosion of a community of trust the society had built" (152). This demonstrates the limitations of the model of globalized Christianity of the early modern period and a sign of the inter-ethnic conflicts, perceptions and exclusions within the church and the Society of Jesus.

The arguments that the book unfolds are compelling and the overall narrative is well developed. There are only some minor issues that can be critiqued. The book, for instance, has no images or illustrations. These would be useful to convey a better sense of the topic and the era described. Second, it would have been useful to include Chinese characters alongside the pinyin in the body of the text, instead of the increasingly outdated glossary of Chinese characters at the end of the book. The footnotes, moreover, could have been more detailed and have included citations in the original, in Chinese, and other languages. All these would have made the book more user-friendly from the scholarly perspective. Yet, no doubt, they pertain more to the responsibilities of the publisher rather than the author.

All in all, The Global Entanglements of a Man Who Never Traveled is an exquisite and erudite work, all while being accessible and skillfully written and narrated: a must have on syllabi of courses of Sino-Western relations, Chinese history, and history of global Christianity.

\title{
Florin-Stefan Morar
}

Harvard University/ City University of Hong Kong

morar@post.harvard.edu

DoI:10.1163/22141332-00603006-03

\section{François Soyer}

Antisemitic Conspiracy Theories in the Early Modern Iberian World: Narratives of

Fear and Hatred. Leiden: Brill 2019. Pp. xvi + 315. Hb, \$238.oo.

François Soyer's new book is a carefully researched study of early modern Iberian conspiracy theories involving conversos - that is, Jewish converts to Catholicism (mostly forced) and their descendants in Spanish and Iberian lands. These theories drew from pre-existing anti-Jewish tropes, but assumed new forms as Spain and Portugal underwent religious, political, and economic transformation in the early modern period. Soyer's thorough gleaning of the primary literature brings together a rich and varied trove of "Old Christian" 
fantasies about conversos conspiring to undermine Christian society. With meticulous attention to the social and political context, he analyzes how these ideas functioned.

Many of the fantasies he explores will be familiar to scholars of pre-modern Iberian (and, more broadly, European) Jewish history. This is also familiar territory for Soyer, who among other things has published a critical edition of Francisco de Torrejoncillo's Centinela contra judios, a source for many of the theories he examines in the book. What Soyer does that is new is to disentangle from the mass of Iberian anti-Jewish ideas those ideas that specifically involved conspiracy, and to analyze them as such. He seeks to show a) that these pre-modern conspiracy theories have a number of features in common with modern anti-Jewish conspiracies; b) that they were popular theories deployed by members of the elite to achieve political and social goals; $\mathrm{c}$ ) that they took their shape in response to particular anxieties in early modern Iberian society; and d) that they served to consolidate a homogeneous collective identity of a kind the post-Tridentine moral order demanded.

While these conclusions are supported by the copious material assembled by Soyer, they are not all novel. The connections between medieval, early modern, and modern antisemitism, conspiracy theories included, have been analyzed by scholars in considerable depth (as Soyer is aware). The deployment of anti-converso propaganda for political and social ends by members of early modern Iberian elites has also been amply explored. As for the argument that anti-converso conspiracies dovetailed with the confessionalizing impulses of the post-Tridentine period, this argument deserves a more penetrating treatment than Soyer's rather brief discussion. Where Soyer is most compelling and innovative is in his discussion of the Iberian mobilization of anti-converso conspiracy theories to express anxiety about such complex and, for contemporaries, inexplicable developments as the sudden Dutch challenge to Hispanic global dominance, the emergence of global commercial networks in which conversos played a disproportionate role, and the widespread perception of Iberian economic decline.

The book could, however, be better integrated. The discussion of scholarly literature on conspiracy theories in the first chapter is important, but stands alone rather than serving as a frame of reference throughout the book. The sense of disjunction is heightened by the division of chapters according to conspiracy types: the international Jewish/converso conspiracy; the plot against the Iberian Catholic Church; the myth of medical murder; the treasonous plot against the state; and the plot to undermine the economy. Yet such clear distinctions have no basis in the primary literature itself. Some of the authors cited - most prominently, Vicente de Costa Mattos, Francisco de Torrejoncillo, 
and Francisco Quevedo-freely mix anti-converso conspiracy theories, signaling that while some accusations might reflect specific anxieties, all of them germinated on common soil. The unified nature of this current of thought is nicely illustrated by a sixteenth-century forged letter Soyer examines-a letter that was subsequently recycled in works by a number of early modern authors-in which the Jews of Constantinople supposedly advised the Jews of Spain (i.e., conversos) to engage in one big plot: They should turn their sons into merchants, in order to seize the Christians' goods; into doctors, to murder the Christians; into clergymen, to destroy their churches; and into lawyers and administrators, to gain political dominion.

The segregation of source material by content category tends to give the book the feel of an exhaustively researched compendium, rather than an attempt to understand the overall emotional and ideational world of anticonverso conspiracism. Possibilities are raised that are not fully pursued. For example, in a chapter that deals with the charge that conversos and Jews conspired together with Protestants to undermine Iberian regimes, Soyer notes that in early Reformation rhetoric Catholic polemicists accused Protestants of "judaizing" in their theology. But he leaves it to the reader to connect the dots - if indeed they can be connected — between such rhetoric and theories of a Jewish-Dutch military conspiracy. Likewise, in his discussion of economic anti-converso conspiracy theories, he acknowledges the importance of the related social issues stemming from the challenge to the landed aristocracy of a rising merchant class, one in which conversos figured heavily. Yet he abandons this important point after two paragraphs.

Notwithstanding these criticisms, the book has much to offer. It examines, along with a well-known set of texts featuring conspiracy theories, an array of more obscure texts that are of great interest to the specialist. Moreover, even when its diverse lines of inquiry are not fully explored, the book can be stimulating and suggestive. Soyer's attention not only to conversos but to the entire range of types targeted by Iberian conspiracy theories hints at a discourse in which "others" - whether conversos, Jews, Protestants, black slaves, moriscos, Amerindians, or imperial rivals - were sometimes imagined to be working malevolently in concert with one another. In a field that has often been balkanized, thus producing a host of studies limited to one group or another, Soyer's acknowledgement of the fact that certain charges of conspiracy were leveled against more than one ethnic, racial, or religious group mirrors a recent and welcome trend, as scholars have begun to recognize the boundary-crossing nature of popular discourse in early modern Iberia.

Let me conclude by emphasizing that despite some shortcomings, Soyer's book, with its wealth of material and flashes of unexpected insight, is an 
invaluable resource for scholars. It should be of special interest to those working in the fields of antisemitism, early modern Iberian history, and the history and function of conspiracy theories.

\section{Miriam Bodian}

The University of Texas at Austin

bodian@austin.utexas.edu

DOI:10.1163/22141332-00603006-04

\section{Barbara B. Diefendorf}

Planting the Cross: Catholic Reform and Renewal in Sixteenth- and Seventeenth-

Century France. Oxford: Oxford University Press, 2019. Pp. xii + 215. Hb. \$74.0o.

In this impressive and engaging book, Barbara Diefendorf examines through six instructive local studies the efforts of regular clergy to reform and renew their communities in the face of the ravages of the French religious wars, and, in many cases, periods of internal decline that predated the wars. Drawing on often never-before used sources in local and departmental archives, Diefendorf uncovers a rich variety of contexts in which reform and renewal took shape driven both by the top-down efforts of leaders and bottom-up campaigns by local reformers and communities. With the exception of the Discalced Carmelites, this book focuses on religious orders that predated the religious wars or were established in France during the conflict. Thus, it places in the background the new religious orders that arrived in France in the seventeenth century and have received a disproportionate amount of scholarly attention to date. It offers a new and welcome perspective into the nature of Catholic renewal in France, one that firmly rejects efforts to generalize or describe a "typical" experience of regular clergy. "Catholic renewal" she argues "was a more diverse, experimental, and experiential process than we often recognize" (2).

Chapter one takes as its focus the three long-established female convents in the overwhelmingly Protestant city of Montpellier, tracing the fraught - and in two cases doomed-efforts by the nuns to survive and then renew their communities. All three foundations were severely disrupted by the wars through repeated expulsions, destruction of their buildings, loss of revenues, collapse in recruitment, and finally abandonment by local elites who preferred new female religious foundations. For these communities reform impulses were largely overwhelmed by the depravations of war. Chapter two shifts our attention to Paris, where the Feuillants house, the most prominent monastery of a recently established reformed group of Cistercians, broke with their 